\title{
The Effect of Speed Reading Strategies on Developing Reading Comprehension among the 2nd Secondary Students in English Language
}

\author{
Mahmoud Sulaiman Hamad Bani Abdelrahman ${ }^{1} \&$ Muwafaq Saleem Bsharah ${ }^{1}$ \\ ${ }^{1}$ Curricula and Instruction Department, Al-Hussain Bin Talal University, Jordan \\ Correspondence: Mahmoud Sulaiman Hamad Bani Abdelrahman, Curricula and Instruction Department, \\ Al-Hussain Bin Talal University, Jordan. Tel: 962-772-618-395. E-mail: Abugaith66@yahoo.com
}

Received: December 17, $2013 \quad$ Accepted: April 3, $2014 \quad$ Online Published: May 15, 2014
$\begin{aligned} & \text { doi:10.5539/elt.v7n6p168 URL: http://dx.doi.org/10.5539/elt.v7n6p168 }\end{aligned}$

\begin{abstract}
This study aimed to find the effect of speed reading strategies on developing reading comprehension among second secondary literary stream students in English language.

The sample of the study consists of (42) students assigned into two groups who were chosen randomly from schools, a controlled group (21) students, and an experimental (21) students trained on speed reading strategies during the academic year 2013/2014.

The study used a training material, pre and post reading comprehension tests were administrated (Rababa'h, 1991). T. test results revealed that there were significant differences at $(\alpha \leq 0.05)$ among the students' means in favor of the experimental group.

In the light of the results, it is recommended that teachers should train students extensively on the use of speed reading strategies.
\end{abstract}

Key words: comprehension, English language, speed reading, strategies

\section{Introduction}

One of the skills in learning English language which should be focused on is the reading comprehension. So, as it is shown, it is given an appropriate weight in the textbooks in Jordanian schools. The main aim of teaching reading is to enable students to comprehend reading from different contents easily. (Ministry of Education, 2002)

Farstrup (2002) stated that teachers should be aware and knowledgeable of many instructional methods and strategies available to promote students' reading comprehension and motivate students towards reading, promote their interest and encouragement in reading comprehension, develop their reading comprehension skills, and aid them in accomplishing reading comprehension tasks successfully.

As specialists in English language teaching, previous teachers of English and psychology, supervisors and headmasters see that to such extent the aim of reading comprehension was not achieved. So, it is shown that students in our schools still face difficulties in answering the questions. The researchers see that this refers to the difficulty in teaching and the reading comprehension texts themselves. As supervisors, headmasters and now university professors of teaching English to non- native speakers' notice that teachers neglect using the speed reading strategies (skimming and scanning) in Jordanian schools. Also, the researchers see that the reading comprehension texts lack enough questions that stimulate students to comprehend information. Harrison (1975), Rivers and Temerely (1978), Nuttal (1982) recommended to use speed reading strategies.

Jarrah (1988) conducted a study to find the effect of using the analytical method on the first secondary graders' achievement in Al-Zarqa area in Jordan. The researcher used speed reading strategies which is similar to the present study. Jarrah (1988) found that there was significant difference at $(\alpha \leq 0.01)$ between the means of both experimental and controlled groups. The researcher recommended the Ministry of Education to train teachers on the use of the analytical method which include the speed reading strategies.

Rababa'h (1991) conducted a study to find the effect of using skimming and scanning in the first secondary science stream students' achievement. He conducted his study on male and female students. The results of his study showed that there was significant difference at $(\alpha \leq 0.05)$ among experimental ones. The researcher said that difference were due to the training on the use of the speed reading strategies. The researcher recommended 
that the Ministry of Education in Jordan should have exercises in the textbooks about the speed reading strategies. Again, he recommended teachers to prepare their own exercises in case the unavailability in some lessons.

The results of this study were with Al-Rababa'h (1991) results as there is an effect for training on the use of speed reading strategies, but this study differs in case it doesn't include female students.

Dyon and Haselgrove (2000) conducted a study and wrote that rapid scanning or skimming of material on screen has become a frequent activity with using a range of questions types, comprehensions was measured after reading from screen at both a normal and fast reading speed. Analysis of the scrolling movements showed that the overall time spent pausing between movements was the best prediction of comprehension.

Salataci and Akyel (2002) conducted a study to investigate the reading strategies of Turkish EFL students in Turkish and English and the possible effects of reading instruction on reading in Turkish and English. The participants consisted of 8 Turkish students. The data came from think-aloud protocols, observation, a background questionnaire, a semi-structured interview and the reading component of the PET (the Preliminary English Test). The results indicated that strategy instruction had a positive effect on both Turkish and English reading strategies and reading comprehension in English.

Chang (2010) carried out a study to develop reading fluency. The researcher used a 13-week timed reading activity was integrated into a normal curriculum with the aim of improving students' reading rates. Participants were 84 college students divided into an experimental and a control group. The test instruments involved pretests and posttests on reading speed and comprehension. Results showed that students doing the timed reading activity increased their reading speed on average by 29 words per minute $(25 \%)$ and comprehension by $63(4 \%)$. Students who did the timed reading activity became confident in their reading.

Bahlool (2013) investigated the effect of using differentiated instruction strategy on developing ninth graders' English reading comprehension skills at Gaza UNRWA Schools. The researcher used two tools, a questionnaire to determine the degree of importance of the reading comprehension skills, an achievement test (Pre \& post test). The sample of the study was 70 male students, (36) in the experimental and (34) in the control. Both groups were pre-tested to assure that they both were equivalent. The findings revealed that there were significant differences between the mean scores attained by the experimental group and those by the control group in favor of the experimental group in all skills. In the light of these results, the researcher recommends that EFL Palestinian teachers should apply differentiated instruction strategy to develop reading comprehension skills.

A lot of studies were conducted to see the effect of using creative thinking on developing reading comprehension skills. Through looking at the results of some studies like Gonzales (2000), Al-Qudah, A-Khataybeh and Mohaidat (2002), Bsharah(2003), Bani Yassin (2005), Clifford (2005) and Al-Eidie (2010), one can notice that using creative thinking gas positive effect on teaching and learning process and it was helpful; it improved students' reading comprehension and develop their attitudes toward reading.

From all the mentioned articles, we see that there is an effect of using speed reading strategies on the students' achievement and their better comprehension.

\section{Material Studied and Background of the Study}

\subsection{The Nature of Speed Reading Strategies}

A lot of writers defined reading as the getting of meaning which the writer means from his or her writing. Flesh (1955) defined reading as getting the meaning from a certain structure to letters. Goodman (1970), Nuttal (1982) and Jacobowitz (1988) agreed as it is an interaction operation. The present researchers agreed with Goodman's definition as reading is an interaction operation that the reader forms expectations about the content he is reading as after that to choose the most practical signs that help to get the meaning.

\subsection{Reading Strategies}

Beale (2013) wrote ideas about speed reading strategies as "people who know how to skim and scan are flexible readers. They read according to their purpose and get information they need quickly without wasting time. They do not need everything which is increases their reading speed. Their skill lies in knowing what specific information to read and which method to read" (p. 1).

The strategies skimming and scanning are well-known and help students to improve their speed. Macleod (2013) wrote that skimming involves a through overview of a text and implies a reading competence. Scanning is more a limited activity, only retrieving information relevant to a purpose. Brown (1994) suggested that "perhaps the two most valuable reading strategies for learners as well as native speakers are skimming and scanning" (p. 283). Pugh (1978) suggested that since scanning is a less complex style of reading it can be introduced first. Skimming 
requires greater fluency and more practice is required, so it should be introduced later.

Skimming: This is reading a text or a passage quickly to get a general idea. Learners do not need to read every word when skimming, so teachers set this as a timed task and to encourage speed. It can be through looking at the title, introduction, and any diagram and sub-titles. Skimming is useful in three different situations. In the pre-reading, reviewing and in the reading process. Different literary methodologists agreed about steps which can be followed in skimming.

1) Read the title

2) Read the introduction or the first paragraph

3) Read the first sentence of every other paragraph

4) Read any headings and sub-headings

5) Notice any pictures, charts, or graphs

6) Notice any italicized or bold face word or phrases

7) Read the summary or last paragraph.

(From http://pioneer.netserv.chula.ac.th/-pkanchan/html/skim.htm).

Scanning: It is to cover a great deal of material rapidly to locate a specific facet or piece of information. It is useful to find specific name, date, statistic, or fact without reading the whole text. In the same website which was mentioned (2013) about skimming, suggested steps to follow in scanning.

1) To keep in mind at all times what are you searching for? If you hold the image of the word or idea clearly in mind, it is likely to appear more clearly than the surrounding words.

2) To anticipate in what form the information is likely to appear, numbers, proper nouns, etc.

3) To analyze the organization of the content before starting to scan.

- If material is familiar, the learner may be able to scan the entire text in a single search.

- If the material is difficult or too long, a preliminary skimming may be necessary to determine which part of the article to scan.

4) Let your eyes run rapidly over several lines of print at a time.

5) When you find the sentence that you seeks, read the entire sentence completely.

Skimming and scanning help in improving the students' speed and help in improving their abilities of comprehension.

Broughton et al. (1980), Smith (1971) and Brower and Bever (1970) agreed that if the learner wants to be fast in comprehending a text, he or she needs to practice skimming and scanning. Through reading different articles, the researchers suggested a way to practice skimming.

1) To get a conclusion

- To get use of the title and sub-titles.

- To read the first and the last sentences of each paragraph.

2) To answer general questions.

- To remember the information we need.

- To determine the things that help to find the answer from the question itself.

- To read the first sentence and the keywords in each paragraph.

- To move the eyes rapidly to get signs about the answers.

- $\quad$ To read the specific part to get the answer.

In talking about scanning, the researchers see that Wirringachitra's (1982) idea is suitable which is similar to what is mentioned in talking about scanning. Speed reading techniques are suggested through browsing in the internet (2013) as follows:

- The hand: Move your hand slowly straight down the page as your eyes follow.

- The card: to move the card to be followed by the brain.

- $\quad$ The sweep: to use the hand to help draw the eyes across the page. 
- The hop: to lift fingers and make two bounced on each line to catch sections of three or four words and then move on.

- The zig-zag: to take the hand and cut the text in a diagonal motion for two or the line. (available at www.scanningessay.com/exams/speed-reading.php)

\section{Methodology}

\subsection{Problem of the Study}

To improve reading process in the secondary stage is a main aim for our curricula in Jordan. The Ministry of Education (1971) introduced the main aim of reading comprehension in English Language is that to help students to read and comprehend English in different contents.

Teachers mostly claim that students suffer from lack of reading comprehension in English language .The researchers think that training students and helping them to acquire the ability to practice scanning and skimming, help students to be improved in their reading comprehension speed. (Al-Alwan \& Bsharah, 2011) .The study aimed to answer the following question:

Are there significant differences in reading comprehension due to the speed reading strategies among the second secondary literary students in English language?

\subsection{The Instructional Material}

To achieve the aims of this study, the researchers used the material which was used by Rababa'h (1991). To check the suitability of the material, the researchers gave the material to specialists, supervisors and teachers for their comments. Then, the researchers took into consideration all the comments and changes to have the material in its final version.

\subsection{Study Hypothesis}

Is there significant difference $(\alpha \leq 0.05)$ in reading comprehension due to speed reading strategies among the $2^{\text {nd }}$ Secondary Students' in English Language?

\subsection{The aim of the Study}

This study aimed at investigating the Effect of Speed Reading Strategies on Developing Reading Comprehension among the $2^{\text {nd }}$ Secondary Students' in English Language.

\subsection{The Importance of the Study}

The importance of the study revealed from the topic it carried out which is expected to be added to educational knowledge. The researchers hope that the results of the study will be taken care from teachers, supervisors and curriculum designers to include speed reading strategies in English language to all levels of students.

\subsection{Definition of Terms (Operational Definitions)}

Skimming: reading a text quickly to get a general idea of meaning.

Scanning: reading in order to find specific information.

Achievement: it means in this study, the achievement of the second secondary students which will be measured through using a test for the aim mentioned.

Secondary Stage: It is the last stage in the Jordanian educational system. It consists of two grades; $1^{\text {st }}$ and $2^{\text {nd }}$ secondary or referred to as $11^{\text {th }}$ and $12^{\text {th }}$ grades.

\subsection{Limitations of the Study}

1) The results of this study can be generalized only on the second secondary literary male students.

2) The results can be generalized on Al-Korah Directorate of Education and similar directorates.

\subsection{Population of the Study}

The population of the study consists of all second secondary students literary stream in Al-Korah Directorate of Education in the academic year 2013/2014. The total number is 32 sections which formed 750 students. All students in this Directorate have the same background and level of life to a large percentage. Their ages are between 18 and 20. All their teachers were at least B.A holders.

\subsection{The Sample of the Study}

The sample of this study was from Al-Ashrafieh secondary school for boys. The sample was chosen as it is the available sample for the researchers and their teachers were good and co-operative teachers. The two sections 
were chosen randomly between controlled and experimental. Section A was the experimental while section B was the controlled one. Twenty-one students were in each section.

\subsection{The Instrument of the Study}

To achieve the aims of the study, the researchers prepared a reading comprehension exam about the reading comprehension. This exam was given after the experiment to see the effect of the experiment and the students' reading comprehension on reading comprehension. The exam consists of two parts to measure the students' abilities of using the speed reading strategies.

\subsection{The Validity of the Exam}

The researchers gave the exam to university professors, supervisors and teachers of English language at schools. They were asked to see the validity of the exam whether it is related and appropriate or not. All agreed that the exam was suitable and can evaluate the students' reading comprehension and abilities on reading comprehension. The researchers computed the correlation coefficient between the degree of item and the total degree on the reading comprehension exam. The item was accepted whenever the correlation coefficient was 0.30 and statistically significant. According to this criterion, all of the items were accepted

\subsection{Reliability of the Exam}

Cronbach Alpha was used and it was $(0.65)$, so, the researchers felt confident about the validity and reliability of the exam.

\subsection{Design of the Study}

The study aims to find the effect of using speed reading strategies on the students' reading comprehension and it includes the following variables:

1) Independent variable: speed reading strategies (skimming and scanning).

2) Dependent variable: This is the students' reading comprehension on speed reading strategies.

\subsection{Statistical Analysis}

T. test was used to test the hypothesis of the study.

\section{Results of the Study}

The aim of the study is to see the effect of using speed reading strategies on the second secondary students' reading comprehension in English language in Jordan during the first semester of the academic year 2013/2014. The hypothesis of the study was that there was no significant difference at $(\alpha \leq 0.05)$ in the second secondary literary stream students' reading comprehension due to training or without training which are due to the use of speed reading strategies. To check the validity of the results, T.test was used. The results are shown in the following table.

Table 1. The results of groups in the pre-test

\begin{tabular}{lccccc}
\hline Group & No. of students & Mean & SD & T.TEST & F \\
\hline Experimental & 21 & 71.75 & 2.61 & 0.74 & 0.35 \\
\hline Controlled & 21 & 68.53 & 4.32 & & \\
\hline
\end{tabular}

Through using T.test at $(\alpha \leq 0.05)$ to compare the means of the two groups, it was found that there was no significant difference between the reading comprehensions of the two groups. The researchers assumed that the two groups were equivalent as it is taken from their marks in the first secondary and the two groups were divided with relation to their levels in the first secondary. So, any difference after training should be due to the training on using the speed reading strategies. After conducting the experiment and giving the post-test to both groups, the hypothesis was checked through using T.test at $(\alpha \leq 0.05)$ and the results as shown in the following table.

Table 2. The results of groups in the post-test

\begin{tabular}{lccccc}
\hline Group & No. of students & Mean & SD & T.TEST & F \\
\hline Experimental & 21 & 87.72 & 1.76 & 13.41 & 0.14 \\
\hline Controlled & 21 & 72.32 & 2.35 & & \\
\hline
\end{tabular}


The results showed the high level of reading comprehension by the experimental group which appears from the means of both experimental and controlled groups. The results showed that there significant difference between the means of both groups due to the use of speed reading strategies. As a result of that, the Null hypothesis was rejected at $(\alpha \leq 0.05)$.

The results showed also that the students in the experimental group were better than the students in the controlled group. The difference between the means was due to the use of speed reading strategies.

\section{Discussion of the Results}

The results of the study showed that there was a significant difference on reading comprehension due to speed reading strategies and that indicated that training was effective for the experimental group which can be due training procedures and the instructional activities improved the students' performance on the reading comprehension scale as there were no learning chances for the controlled group. The students who participated in the study showed the motivation and attraction during the training sessions based on speed reading strategies which agreed with the theoretical background of the same studies like Broughton et al. (1980), Bever and Bover (1970) and Waldman (1972) about the importance of using speed reading strategies to improve the students' comprehension The results of the study agreed with Baunann's (1984), Barnett's (1988) and Rababa'h's (1991) results in their studies of training students on comprehension skill to get the main idea. The result approved what Mackenzie (2011) clarified about the thinking through reading comprehension strategies that should follow the following steps : Making Connections, Retelling, Visualizing, Asking Questions, Making Predictions, Making Inferences, Understanding Text Structure, Determining Importance, Identifying the Author's Message, and Synthesizing.

\section{Recommendations}

The researchers recommended

1) The Ministry of Education in Jordan should include exercises of speed reading on reading comprehension in English language textbooks.

2) The Ministry of Education in Jordan should train teachers mainly the newly appointed on the use of speed reading strategies.

3) Teachers should prepare in advance exercises including speed reading strategies if they are unavailable in any class.

\section{References}

Adams, A., Garnine, D., \& Gersten, R. (1982). International Strategies for Studying Content Area Texts in the Intermediate Grades. Reading Research Quarterly, 18(1), 27-55.

Al-Alwan, A., \& Bsharah, M. (2011). The effectiveness of proposed reading strategy (KWL) to activate the background knowledge in reading comprehension of a sample of Tenth Grade Students in Ma'an city. Studies Journal, University of Jordan, 38(1).

Al-Eidie, R. A. (2010). The Effect of Using Creative Thinking Skills on the Development of Reading Comprehension of Female Tenth Grade Students in Southern Al-Mazar Directorate of Education (Unpublished M.A.thesis, Mu'tah University, Jordan).

Al-Qudah, M., Al-Khataybeh, M., \& Mohaidat, M. (2002). Reading Comprehension: Influence of Brainstorming. Abhath Al-Yarmouk, 18(3B), 109-120.

Bahlool, A. (2013). The Effect of Differentiated Instruction Strategy on Developing Ninth Graders' English Reading Comprehension Skills at Gaza UNRWA Schools (Unpublished M.A. thesis, the Islamic University of Gaza).

Barnett, M. (1988). Teaching Reading Strategies: How Methodology Affects Course Articulation. Journal of Foreign Language Annals, 21(2), 109-115.

Baumann, J. (1984). The Effectiveness of a Direct Method Instruction Paradigm for Teaching Main Idea Comprehension. Reading Research Quarterly, 20(1), 93-105.

Beale, A. M. (2013). Anne Arundal Community College. Retrieved from www.aacc.ed/tutoring/file/skimming.pdf

Bever, T., \& Bower, T. (1970). How to read without listening. In M. Lester (Ed.), Readings in Applied Transformational Grammar. New York: Holt, Rinehart and Winston. 
Brown, D. (1994). Teaching by principles: An interactive approach to language pedagogy. Upper Saddle River, Prentice Hall Regents.

Bsharah, M. (2003). The Effect of A training Program for Higher Order Thinking Skills on Developing Critical and Creative Thinking Skills of $10^{\text {th }}$ Grade Students (Unpublished Ph.D dissertation, Yarmouk University).

Chang, A. (2010). The effect of a timed reading activity on EFL learners: Speed, comprehension, and perceptions. Reading in a Foreign Language, 22(2), 284-303.

Clarke, M., \& Silberstein, S. (1979). Towards a realization of psycholinguistic principles in the ESL classroom. In R. Mackay et al. (Ed.), Reading in A Second Language. Newbury House Publishers, Inc. Rowley.

Clifford, A. (2005). Assessing the Use of Creative Problem Solving Skills and Generic Influences on Learning in Clinical Reasoning by Physician Assistant Students (Ph.D, Drexel University, USA).

Farstrup, A. (2002). What research has to say about Reading Instruction. Newark, DE: International Reading Association.

Gonzales, D. (2000). The Effectiveness of a Language Experience Approach in Improving Creative Writing Skills of Limited and Non-English Proficient Students in an "Author Center Program" (Ph.D. The Claremount Graduate University, U.S.A).

Goodman, K. (1970). Reading: A psycholinguistic guessing game. In H. Singer, \& R. B. Ruddel (Ed.), Theoretical Models and Processes of Reading. Newark, Del: International University Press.

Goodman, K. (1971). Psycholinguistic universals in the reading process. In P. Pimsleur, \& T. Quinn (Ed.), The Psychology of Second Language Learning. Cambridge: Cambridge University Press.

Jarrar, A. (1988). The Effect of Using the Analytical Method on the Achievement of First Secondary Class Students in Reading Comprehension (Unpublished M.A. thesis, University of Jordan).

Mackenzie, A. (2011). Reading Comprehension Strategies. Retrieved March 14, 2014, from ReadingComprehensionLessons.com

Macleod, M. (2013). Types of Reading. Retrieved from fis.ucalgary.ca/Brian/611/reading type.Html \#references

Mary, C. D., \& Mark, H. (2000). The effect of reading speed and reading pattern on the understanding of text read from screen. Journal Research Reading, 23(2), 260-273.

Ministry of Education. (1971). English Curriculum: Secondary Stage. Amman, Jordan.

Ministry of Education. (2002). English Curriculum: Secondary Stage. Amman, Jordan.

Nuttal, C. (1982). Teaching Reading Skills in a Foreign Language. Heinmann Educational Books, London.

Pugh, A. K. (1978). Silent Reading-An introduction to its study and teaching. London: Heinemamm Educational Books.

Rababa'h, G. (1991). The Effect of Using Skimming and Scanning on First Secondary Scientific Class Students' Achievement in Reading Comprehension (Unpublished M.A. thesis, Yarmouk University).

Salataci, R., \& Akyel, A. (2002). Possible Effects of Strategy Instruction on L1 and L2 Reading. Reading in a Foreign Language, 14(1), 1-17.

Speed Reading. (2013). Retrieved from www.scanningessay.com/exams/speed-readingh.php

Waldman, J. (1972). Reading with Speed and Confidence. Random House, New York.

Widdowson, H. (1979). Explorations in Applied Linguistics. Oxford University Press.

Wiriyachitra, A. (1982). A scientific reading program. English Teaching FORUM, 20(3), 20-23.

Yassin, T. B. (2005). The Effect of Teaching Creative Thinking Skills through Arabic Language on Reading comprehension and Creative Abilities for Third Grade Primary Students in Amman (Unpublished M.A. thesis, University of Jordan, Amman, Jordan).

\section{Copyrights}

Copyright for this article is retained by the author(s), with first publication rights granted to the journal.

This is an open-access article distributed under the terms and conditions of the Creative Commons Attribution license (http://creativecommons.org/licenses/by/3.0/). 